\title{
Caracterização da Agressividade de Isolados de Colletotrichum de Maracujá Amarelo com Marcadores Bioquímico, Fisiológico e Molecular
}

\author{
Luiz Carlos C. Almeida ${ }^{1}$ \& Rildo S.B. Coêlho
}

${ }^{1}$ CEPLAC/CEPEC/Seção de Fitopatologia, Cx. Postal 7, CEP 45600-970, Itabuna, BA, Brasil, e-mail: cordeirolc@yahoo.com.br; ${ }^{2}$ Setor de Fitossanidade, Departamento de Agronomia, Universidade Federal Rural de Pernambuco, Dois Irmãos, CEP 52171-900, Recife, PE, Brasil, e-mail: rsartori@oi.com.br

Autor para correspondência: Luiz Carlos C. Almeida

ALMEIDA, L.C.C. \& COÊLHO, R.S.B. Caracterização da agressividade de isolados de Colletotrichum de maracujá amarelo com marcadores bioquímico, fisiológico e molecular. Fitopatologia Brasileira 32:318-328. 2007.

\section{RESUMO}

A antracnose é a doença pós-colheita mais importante do maracujá amarelo, cujo agente etiológico, no Brasil, foi identificado como Colletotrichum gloeosporioides. Visando caracterizar o patógeno, foram obtidos 33 isolados de três regiões produtoras do estado de Pernambuco. Critérios morfológicos como cor de colônia, forma e dimensão de conídios, a produção de peritécio e o uso de primers específicos para C. acutatum, C. gloeosporioides e "Colletotrichum de Passiflora" permitiram identificar Glomerella cingulata patótipo 1, G. cingulata patótipo 2, Colletotrichum sp. de Passiflora e Colletotrichum sp. de maracujá amarelo. Inoculações em maracujá amarelo possibilitaram separar os isolados em dois grupos, um de agressividade alta (GA-1) e outro de agressividade baixa (GA-2). Os marcadores bioquímicos como atividade enzimática amilolítica, celulolítica, lipolítica e proteolítica assim como o marcador fisiológico crescimento micelial não separaram os isolados pela agressividade. O padrão de marcas geradas pela amplificação dos DNAs dos isolados usando primers RAPD evidenciou que os isolados do GA-1 variaram menos geneticamente entre si do que os isolados do GA-2, demonstrando que os do GA-1 evoluíram mais recentemente. A amplificação do DNA dos isolados com o primer OPA-9 gerou um marcador que possibilitou caracterizar 85,7\% dos isolados do GA-1 e também alguns isolados do GA-2 com agressividade próxima às dos isolados do GA-1, e por isto o primer OPA-9 pode ser usado para caracterizar isolados de Colletotrichum spp. de alta agressividade em programa de resistência genética.

Palavras-chave adicionais: Passiflora edulis f. flavicarpa, antracnose, pós-colheita, RAPD, PCR.

\begin{abstract}
Characterization of aggressiveness of Colletotrichum isolates from yellow passion fruit by biochemical, physiological and molecular markers

Anthracnose is the most important post harvest disease of yellow passion fruit, whose etiologic agent has been identified in Brazil as Colletotrichum gloeosporioides. For pathogen characterization, 33 isolates were obtained from three producing regions of Pernambuco State. Morphological characters, such as color of the colony, conidial form and dimension, perithecium production and specific primers for C. gloeosporioides, C. acutatum and "Colletotrichum of Passiflora" allowed the identification of Glomerella cingulata pathotype 1, G. cingulata pathotype 2, Colletotrichum sp. from Passiflora and Colletotrichum sp. from yellow passion fruit. Yellow passion fruit inoculations showed two isolate groups, one with high aggressiveness (GA1) and another with low aggressiveness (GA-2). Biochemical markers, such as amilolytic, cellulolytic, lipolytic and proteolytic enzymatic activities and physiological markers, such as mycelial growth, did not separate isolates into groups by aggressiveness. Standard markers produced by DNA amplification of isolates, using RAPD primers, showed that GA-1 isolates were more genetically related to each other than GA-2 isolates, evidencing GA-1 isolates with more recent evolution. The DNA amplifications of isolates with OPA-9 primer generated a marker that allowed grouping of 85.7\% of GA-1 isolates, but included some GA-2 isolates with aggressiveness close to that of GA-1 isolates; therefore, OPA-9 primer can be used to characterize Colletotrichum spp. isolates with high aggressiveness in genetic resistance programs.
\end{abstract}

Additional keywords: Passiflora edulis f. flavicarpa, anthracnose, post harvest, RAPD, PCR.

\section{INTRODUÇÃO}

Uma das doenças mais importantes do maracujazeiro amarelo (Passiflora edulis Sims. f. flavicarpa Deg.) na

Parte da Tese de Doutorado do primeiro autor. Universidade Federal Rural de Pernambuco. Recife PE. 2005. pós-colheita é a antracnose (Silva \& Durigan, 2000), caracterizada pela presença de manchas ou podridões na superfície dos frutos (Peruch, 1998), resultantes de infecções quiescentes ocorridas no campo (Benato, 1999). Os frutos são descartados quando apresentam muitos desses sintomas durante a comercialização (Teixeira, 1995).

O agente etiológico até então identificado no Brasil é o fungo Colletotrichum gloeosporioides (Penz.) Penz. \& 
Sacc. (Liberato, 2002). Entretanto, na Colômbia, isolados de Passiflora foram identificados como Colletotrichum spp. com base em estudo molecular utilizando primers da região ITS (internal transcribed spaces), desenhados para C. gloeosporioides, C. acutatum J.H. Simmons e isolados de Colletotrichum de uma população de Passiflora (AfandorKafuri et al., 2003). Como medida de controle Wulff et al. (1994) sugerem a adoção de cultivares com maior nível de resistência para aumentar a eficácia das práticas de manejo recomendadas para o maracujazeiro.

Na busca por material botânico resistente à antracnose tem sido explorada a variabilidade do patógeno. DenoyesRothan et al. (1999), ao estudarem a seleção de genótipos de morangos (Fragaria $X$ ananassa Duch.) resistentes, inocularam o isolado mais virulento de C. acutatum. Denoyes-Rothan et al. (2003), no estudo da interação entre isolados do patógeno e o morangueiro, detectaram dois grupos de patogenicidade. A produção das enzimas extracelulares com atividades amilolítica, celulolítica, lipolítica e proteolítica em meio sólido permitiu comparar em banana (Musa spp.) a variabilidade entre isolados de $C$. musae (Berk. \& M.A. Curtis) Arx (Couto et al., 2002); o crescimento micelial evidenciou a variabilidade de isolados de C. gossypii var. cephalosporioides A.S. Costa de algodão (Gossypium hirsutum L.) (Lima \& Chaves, 1992). Primers de RAPD (random amplified polymorphic DNA) permitiram conhecer a diversidade de isolados de Colletotrichum gloeosporioides de vários hospedeiros tais como abacate, mamão, banana, manga, seringueira, estilosantes e morango (Mills et al., 1992).

Métodos tradicionais como forma e dimensões dos conídios, coloração das colônias e taxa de crescimento micelial, apesar de amplamente utilizados, não são suficientes para diferenciação dos isolados de Colletotrichum por causa da alta variabilidade do patógeno (Afanador-Kafuri et al., 2003; Freeman et al., 1998). Por outro lado, primers de PCR (polymerase chain reaction) da região ITS1 vêm sendo utilizados como marcadores confiáveis para identificação de $C$. gloeosporioides e $C$. acutatum, isolados de vários hospedeiros, sem ter sido dada importância aos hospedeiros dos quais foram isoladas as espécies de Colletotrichum que deram origem aos referidos primers (Afanador-Kafuri et al., 2003; Freeman et al, 1998).

Neste trabalho, procurou-se conhecer a agressividade de isolados de Colletotrichum de maracujá amarelo oriundos de três regiões do estado de Pernambuco, caracterizá-la com marcadores bioquímico, fisiológico e molecular, e identificar os isolados a nível de espécie de modo que os resultados obtidos possam subsidiar estudos sobre a resistência de frutos de maracujá à antracnose.

\section{MATERIAL E MÉTODOS}

\section{Coleta e identificação de isolados de Colletotrichum de maracujá amarelo}

Frutos de maracujazeiro amarelo com sintomas de antracnose foram coletados em plantações da Zona da Mata Norte (ZMN), Zona da Mata Sul (ZMS) e do Agreste (AGR) do estado de Pernambuco em 2002. Fragmentos foram retirados das lesões e colocados em meio BDA, vertido em placas de Petri. As placas foram mantidas em temperatura de $25 \pm 2^{\circ} \mathrm{C}$ e sob luz contínua. As colônias desenvolvidas, nas quais observou-se a cor do micélio, a forma e dimensões dos conídios e a presença de peritécios, resultaram na obtenção de 33 isolados que foram identificados com a sigla Cm (Colletotrichum de maracujá). Os isolados foram cultivados em meio líquido de batata-dextrose para produção de micélio, que foi coletado, lavado, retirado o excesso de umidade e liofilizado.

O DNA dos isolados foi extraído conforme protocolo de Faleiro et al. (2004), com modificações, aumentando para $800 \mu \mathrm{L}$ o tampão de lise e reduzindo o tempo de incubação para 30 min. Na desproteinização, adicionou-se um volume de clorofórmio-álcool isoamílico (24:1) ao sobrenadante. Para a precipitação do DNA, adicionou-se ao sobrenadante $500 \mu \mathrm{L}$ de isopropanol $\left(-20^{\circ} \mathrm{C}\right)$ e $\mathrm{NaCl}$ para se atingir concentração de 57,6 mM. O DNA precipitado foi lavado duas vezes com $300 \mu \mathrm{L}$ de etanol $70 \%$ e ressuspendido em $150 \mu \mathrm{L}$ água, contendo $40 \mu \mathrm{g}$ de RNAse/mL, em banhomaria por $30 \mathrm{~min}$.

Para identificação taxonômica dos isolados de Colletotrichum utilizou-se o primer ITS4 (TCCTCCGCTTATTGATATGC) combinado com um dos primers específicos para C. acutatum isolado de morango (CaInt2-GGGGAAGCCTCTCGCGG) (Sreenivasaprasad et al., 1996), para C. gloeosporioides isolado de hospedeiros não descritos (CgInt-GGCCTCCCGCCTCCGGGCGG) (Mills et al., 1992) ou para Colletotrichum isolado de uma população de Passiflora (Col1-GCCGTCCCCTGAAAAG) (Afanador-Kafuri et al., 2003). Os primers CaInt2, CgInt e Col1 fazem parte da região ITS1 do rDNA. Fragmentos de DNA da região ITS de cada isolado foram amplificados pela técnica de Williams et al. (1990), com reação totalizando $25 \mu \mathrm{L}$, contendo Tris- $\mathrm{HCl}(\mathrm{pH} 8,8) 75 \mathrm{mM},\left(\mathrm{NH}_{4}\right)_{2} \mathrm{SO}_{4} 20$ $\mathrm{mM}$, Tween 20 0,01\%, $\mathrm{MgCl}_{2} 1,2 \mathrm{mM}, 2,5 \mu \mathrm{M}$ de cada dNTP, $0,4 \mu \mathrm{M}$ de cada um dos primers de PCR (fornecidos pela Invitrogen), quatro unidades da enzima Taq polimerase (Fermentas) e, aproximadamente, 30 ng de DNA. As reações foram realizadas em termociclador Eppendorf Mastercycler Gradient, sob as seguintes condições térmicas: $94^{\circ} \mathrm{C}$ por dois min; 40 ciclos de $94^{\circ} \mathrm{C}$ por $15 \mathrm{~s}, 35^{\circ} \mathrm{C}$ por $30 \mathrm{~s}, 72^{\circ} \mathrm{C}$ por $90 \mathrm{~s} \mathrm{e} 72^{\circ} \mathrm{C}$ por $7 \mathrm{~min}$. Os fragmentos amplificados foram separados por eletroforese, em gel de agarose $1,2 \%$ contendo brometo de etídio, e visualizados sobre luz ultravioleta.

\section{Estudo da agressividade dos isolados de Colletotrichum sobre maracujá amarelo}

Frutos sadios de maracujazeiro amarelo, em fase intermediária de maturação, foram desinfestados de acordo com metodologia de Lima Filho et al. (2003) e receberam ferimentos em quatro locais eqüidistantes um do outro, com um perfurador de cinco pontas ( $5 \mathrm{~mm}$ de diâmetro e $2 \mathrm{~mm}$ 
de profundidade) flambado. Sobre os ferimentos depositouse o inóculo, disco de micélio cultivado em BDA (5 mm de diâmetro), dos isolados (tratamento) e disco de BDA (testemunha). Cada fruto foi colocado em câmara úmida por $48 \mathrm{~h}$. As avaliações foram realizadas sete dias após a inoculação, medindo-se, em dois sentidos perpendiculares, o diâmetro da lesão (DL), expresso em mm. O reisolamento do fungo foi efetuado para comparar as colônias obtidas com aquelas utilizadas como inóculo.

O desenho experimental foi inteiramente casualizado, com 34 tratamentos (33 isolados + testemunha) e cinco repetições. Foi realizada análise de variância dos dados e testada a sua homogeneidade usando o teste de Bartlet, e as médias dos tratamentos foram comparadas entre si pelo teste de Scott-Knot $(\mathrm{P}=0,05)$.

Correlação da agressividade dos isolados de Colletotrichum com a produção de enzimas hidrolíticas extracelulares e com o crescimento micelial

O inóculo dos isolados de Colletotrichum foi transferido para o centro de placas de Petri, contendo um dos meios específicos às atividades amilolítica, celulolítica, lipolítica, proteolítica e pectinolítica, e também ao crescimento micelial. As placas foram incubadas a $25 \pm$ $2^{\circ} \mathrm{C}$ e sob luz contínua. Para testar a habilidade dos isolados em degradar amido, lipídio e pectina em meio ácido foram adotados os métodos descritos por Hankin \& Anagnostakis (1975); para degradar celulose, seguiu-se a metodologia de Neirotti \& Azevedo (1988); e para degradar proteína, utilizou-se o método de Barbosa (1998).

O crescimento micelial dos isolados foi avaliado em meio de BDA, seis dias após a inoculação. Em cada ensaio utilizou-se o delineamento experimental inteiramente casualizado, com 33 tratamentos e cinco repetições. Os halos de degradação dos substratos em torno da colônia e o crescimento micelial em BDA foram avaliados por duas medições perpendiculares, expressas em mm. Foi realizada a análise de variância dos dados, sendo as médias comparadas entre si pelo teste de Scott-Knot $(\mathrm{P}=0,05)$. Também estudouse a correlação destes dados com os de agressividade, usando o programa SAS, adotando o método de Pearson, e foi estabelecida a probabilidade de 5\% (SAS Institute, 1998).

\section{Análise molecular de isolados de Colletotrichum e caracterização da agressividade com primer de RAPD}

Para identificação de marcadores RAPD capazes de caracterizar a agressividade dos isolados de Colletotrichum, os DNAs extraídos foram amplificados usando-se a técnica de Williams et al. (1990), descrita anteriormente, com um dos seguintes primers, resultantes de uma seleção prévia: OPA-2, OPA-3, OPA-9, OPA-10, OPA-11, OPA-12, OPA-13, OPH-4, OPH-5, ОРH-7, ОРН-8, ОРН-9, ОРН-15, ОРН-18, OPM-15, OPN-4, OPN-14 e OPP-19 (Operon Technologies Inc.).

O estudo da associação de marcas moleculares com a característica fenotípica agressividade foi realizado através da análise de regressão linear múltipla da variável fenotípica, em função das variáveis moleculares (marcas RAPD), usando o método de seleção por etapa, Stepwise - PROC REG (SAS Institute, 1998), com o nível de 1\% de probabilidade para inclusão e preservação das variáveis no modelo. O estudo das dissimilaridades genéticas foi realizado usando o programa GENES (Cruz, 2000), partindo-se da matriz 1 - índice de Jaccard, que deu origem a um gráfico de dispersão dos isolados considerando como referencial lesões superiores e inferiores a 12,00 mm, estabelecidas pelo teste de Scott Knott. Para o agrupamento dos isolados foi usado o procedimento Cluster Analyses (SAS Institute, 1998), modelo Centróide usado por Cruz (2000), a partir da matriz de distâncias 1 - índice de Jaccard, construída com a consideração das variáveis moleculares.

\section{RESULTADOS E DISCUSSÃO}

\section{Coleta e identificação de isolados de Colletotrichum de maracujá amarelo}

A partir de frutos de maracujá amarelo com antracnose foi possível obter 18 isolados de Colletotrichum spp. do AGR, sete da ZMS e oito da ZMN (Tabela 1).

As colônias desenvolveram micélio de cor branca, cinza claro, cinza escuro, oliva escuro e rosa. Todas estas cores correspondem às de C. gloeosporioides (Bernstein et al., 1995; Gunnell \& Bubler, 1992; Swart, 1999) embora a cor rosa tenha sido associada a C. acutatum (Bernstein et al., 1995), sendo que nesta espécie a parte superior das colônias pode variar de branco a cinza e a parte inferior de branco a rosa (Gunnell \& Bubler, 1992; Sutton, 1992).

Os conídios apresentaram forma oblonga, extremidades obtusas, e dimensões entre 12-17 x 3,5-6 $\mu \mathrm{m}$, que os identificam como C. gloeosporioides (Bernstein et al., 1995; Gunnell \& Bubler, 1992; Sutton, 1992).

Nos frutos e no meio de cultura os isolados $\mathrm{Cm} 5,11$, $15,16,18,21$ e 23 produziram peritécios, com características de Glomerella cingulata (Stoneman) Spauld. \& H. Schrenk, de acordo com a descrição de Bryson et al. (1992), sendo esta espécie o teleomorfo de C. gloeosporioides (Sutton, 1992).

Os DNAs dos 33 isolados de Colletotrichum não foram amplificados com os primers CaInt2 e CgInt da região ITS1, desenhados respectivamente para $C$. acutatum (Figura 1A) e C. gloeosporioides (Figura 1B), mas apenas os DNAs dos isolados Cm1, 2, 3, 6, 9, 10, 12, 13, 16, 17, 20, 23, 24, 27, 28 e 29 foram amplificados com o primer Col1da região ITS1, desenhado para Colletotrichum de Passiflora (Figura 1C). Esses resultados são semelhantes aos obtidos por Afanador-Kifuri et al. (2003).

Apesar de todos os isolados terem apresentado cor de colônia e conídios com forma típica de C. gloeosporioides, nenhum DNA foi amplificado com o primer específico CgInt. Os DNAs dos isolados que apresentaram colônias de coloração típica de $C$. acutatum também não foram amplificados com o primer específico $C a$ Int2. Isto demonstra 
TABELA 1 - Agressividade de isolados de Colletotrichum spp. de maracujá amarelo, expressa pelo diâmetro de lesão, relacionados segundo suas regiões de origem, tipo de reprodução, grupo de agressividade, grupo genético e com marcas de primers de RAPD

\begin{tabular}{|c|c|c|c|c|c|c|c|c|}
\hline \multirow[t]{2}{*}{ Isola do } & \multirow{2}{*}{$\begin{array}{c}\text { Diâmetro } \\
\text { de lesão }{ }^{1} \\
(\mathrm{~mm})\end{array}$} & \multirow{2}{*}{$\begin{array}{c}\text { Região } \\
\text { de origem }^{3}\end{array}$} & \multirow{2}{*}{$\begin{array}{c}\text { Tipo de } \\
\text { reprodução }\end{array}$} & \multirow{2}{*}{$\begin{array}{c}\text { Grupo } \\
\text { de } \\
\text { agressividade }^{5}\end{array}$} & \multirow{2}{*}{$\begin{array}{c}\text { Grupo } \\
\text { genético }^{6}\end{array}$} & \multicolumn{3}{|c|}{ Marca de primer de RAPD } \\
\hline & & & & & & OPA9 $^{7}$ & OPN14 ${ }^{8}$ & OPH$_{18}^{9}$ \\
\hline $\mathrm{Cm} 17$ & $19,10^{2} \mathrm{a}$ & AGR & A & 1 & 2 & $1^{10}$ & 0 & 1 \\
\hline $\mathrm{Cm} 20$ & $18,46 \mathrm{a}$ & AGR & $\mathrm{A}$ & 1 & 1 & 1 & 0 & 0 \\
\hline $\mathrm{Cm} 19$ & $17,52 \mathrm{a}$ & AGR & A & 1 & 1 & 1 & 0 & 0 \\
\hline $\mathrm{Cm} 03$ & $17,08 \mathrm{a}$ & ZMS & A & 1 & 1 & 1 & 0 & 0 \\
\hline $\mathrm{Cm} 01$ & $16.68 \mathrm{a}$ & ZMS & A & 1 & 1 & 1 & 0 & 0 \\
\hline $\mathrm{Cm} 12$ & $16,32 \mathrm{a}$ & AGR & A & 1 & 1 & 1 & 0 & 0 \\
\hline $\mathrm{Cm} 10$ & $16,02 \mathrm{a}$ & ZMS & A & 1 & 1 & 1 & 0 & 0 \\
\hline $\mathrm{Cm} 13$ & $15,28 \mathrm{a}$ & AGR & $\mathrm{A}$ & 1 & 1 & 1 & 0 & 0 \\
\hline $\mathrm{Cm} 18$ & $14,92 \mathrm{a}$ & AGR & $\mathrm{S}$ & 1 & 2 & 0 & 0 & 1 \\
\hline $\mathrm{Cm} 30$ & $14,42 \mathrm{a}$ & $\mathrm{ZMN}$ & A & 1 & 2 & 0 & 0 & 1 \\
\hline $\mathrm{Cm} 31$ & $14,06 \mathrm{a}$ & $\mathrm{ZMN}$ & $\mathrm{A}$ & 1 & 1 & 1 & 0 & 0 \\
\hline $\mathrm{Cm} 23$ & 13,44 a & AGR & $\mathrm{S}$ & 1 & 1 & 1 & 0 & 0 \\
\hline $\mathrm{Cm} 06$ & $13,32 \mathrm{a}$ & $\mathrm{ZMN}$ & $\mathrm{A}$ & 1 & 1 & 1 & 0 & 0 \\
\hline $\mathrm{Cm} 32$ & $12,66 \mathrm{a}$ & ZMS & $\mathrm{A}$ & 1 & 1 & 1 & 0 & 0 \\
\hline $\mathrm{Cm} 07$ & $11,78 \mathrm{~b}$ & $\mathrm{ZMN}$ & A & 2 & 2 & 0 & 0 & 1 \\
\hline $\mathrm{Cm} 02$ & $11,74 \mathrm{~b}$ & ZMS & A & 2 & 1 & 1 & 0 & 0 \\
\hline $\mathrm{Cm} 27$ & $11,54 \mathrm{~b}$ & AGR & A & 2 & 1 & 1 & 0 & 0 \\
\hline $\mathrm{Cm} 15$ & $11,20 \mathrm{~b}$ & AGR & $\mathrm{S}$ & 2 & 2 & 0 & 1 & 1 \\
\hline $\mathrm{Cm} 25$ & $11,20 \mathrm{~b}$ & AGR & A & 2 & 2 & 0 & 0 & 1 \\
\hline $\mathrm{Cm} 29$ & $10,90 \mathrm{~b}$ & $\mathrm{ZMN}$ & A & 2 & 1 & 1 & 0 & 0 \\
\hline $\mathrm{Cm} 22$ & $10,80 \mathrm{~b}$ & AGR & A & 2 & 2 & 0 & 1 & 1 \\
\hline $\mathrm{Cm} 08$ & $10,32 \mathrm{~b}$ & $\mathrm{ZMN}$ & $\mathrm{A}$ & 2 & 2 & 0 & 0 & 1 \\
\hline $\mathrm{Cm} 16$ & $10,14 \mathrm{~b}$ & AGR & $\mathrm{S}$ & 2 & 2 & 0 & 0 & 1 \\
\hline $\mathrm{Cm} 14$ & $10,12 \mathrm{~b}$ & AGR & $\mathrm{A}$ & 2 & 2 & 0 & 0 & 1 \\
\hline $\mathrm{Cm} 33$ & $9,70 \mathrm{~b}$ & ZMS & A & 2 & 2 & 0 & 0 & 0 \\
\hline $\mathrm{Cm} 04$ & $9,64 \mathrm{~b}$ & $\mathrm{ZMN}$ & A & 2 & 2 & 0 & 0 & 0 \\
\hline $\mathrm{Cm} 09$ & $9,00 \mathrm{~b}$ & ZMS & A & 2 & 1 & 0 & 0 & 0 \\
\hline $\mathrm{Cm} 24$ & $8,82 \mathrm{~b}$ & AGR & A & 2 & 2 & 0 & 0 & 0 \\
\hline $\mathrm{Cm} 28$ & $7,72 \mathrm{~b}$ & AGR & A & 2 & 2 & 0 & 0 & 0 \\
\hline $\mathrm{Cm} 26$ & $7,70 \mathrm{~b}$ & AGR & A & 2 & 2 & 0 & 1 & 1 \\
\hline $\mathrm{Cm} 11$ & $6,64 \mathrm{~b}$ & AGR & A & 2 & 2 & 0 & 1 & 1 \\
\hline $\mathrm{Cm} 05$ & $6,12 \mathrm{~b}$ & $\mathrm{ZMN}$ & $\mathrm{S}$ & 2 & 2 & 0 & 1 & 1 \\
\hline $\mathrm{Cm} 21$ & $3,88 \mathrm{~b}$ & AGR & S & 2 & 2 & 0 & 1 & 1 \\
\hline \multicolumn{9}{|c|}{$\begin{array}{l}{ }^{1} \text { Média de cinco repetições; } \\
{ }^{2} \text { Médias seguidas de mesma letra não diferem pelo teste de Skot } \\
{ }^{3} \mathrm{AGR}=\text { Agreste, } \mathrm{ZMS}=\text { Zona da Mata Sul, e } \mathrm{ZMN}=\text { Zona da Mat } \\
{ }^{4} \mathrm{~A}=\text { Assexuada e } \mathrm{S}=\text { Sexuada; } \\
{ }^{5} 1=\text { Alta agressividade e } 2=\text { Baixa agressividade; } \\
{ }^{6} \text { Resultado da análise do polimorfismo de } 250 \text { fragmentos de DI } \\
{ }^{7} \text { Relativa à quarta marca do isolado } \mathrm{Cm} 17 \text { no gel de agarose; } \\
{ }^{8} \text { Relativa à terceira marca do isolado } \mathrm{Cm} 15 \text { no gel de agarose; } \\
{ }^{9} \text { Relativa à segunda marca do isolado Cm } 17 \text { no gel de agarose; } \\
{ }^{10} 1 \text {, presença de fragmentos e } 0 \text {, ausência; }\end{array}$} \\
\hline
\end{tabular}

a incongruência entre critérios morfológicos e moleculares para identificação de espécies em Colletotrichum. Observações iguais a estas foram feitas por Afanador-Kifuri et al. (2003) ao identificar isolados de Colletotrichum em tamarindo, Passiflora e manga.

Com base nos resultados obtidos, os isolados $\mathrm{Cm} 5$,
11, 15, 18 e 21 podem ser identificados como Glomerella cingulata, patótipo 1 , porque produziram peritécios típicos dessa espécie; os isolados $\mathrm{Cm} 16$ e $\mathrm{Cm} 23$ podem ser considerados como Glomerella cingulata, patótipo 2, porque além de terem produzido peritécios típicos dessa espécie, seus DNAs foram amplificados pelo primer Col1; 
A

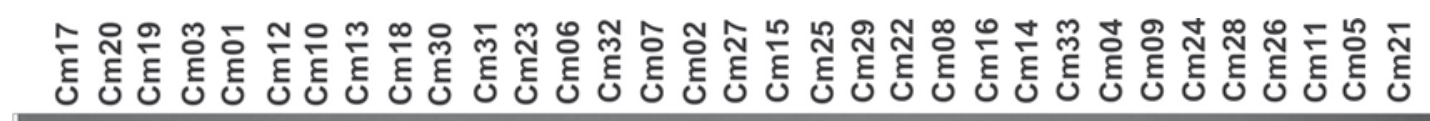

A

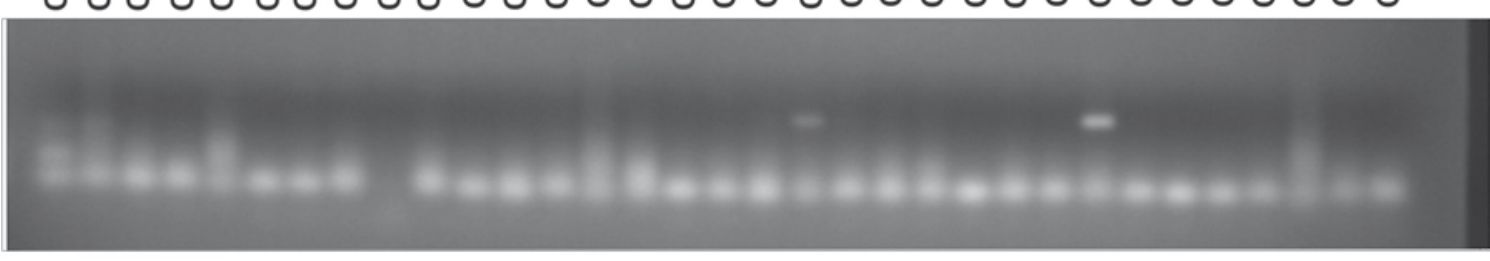

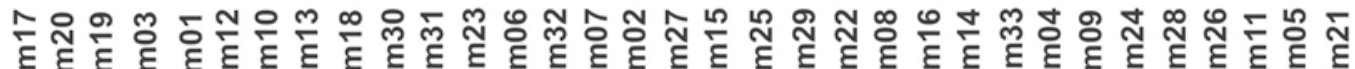

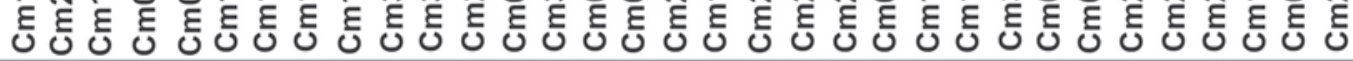

B
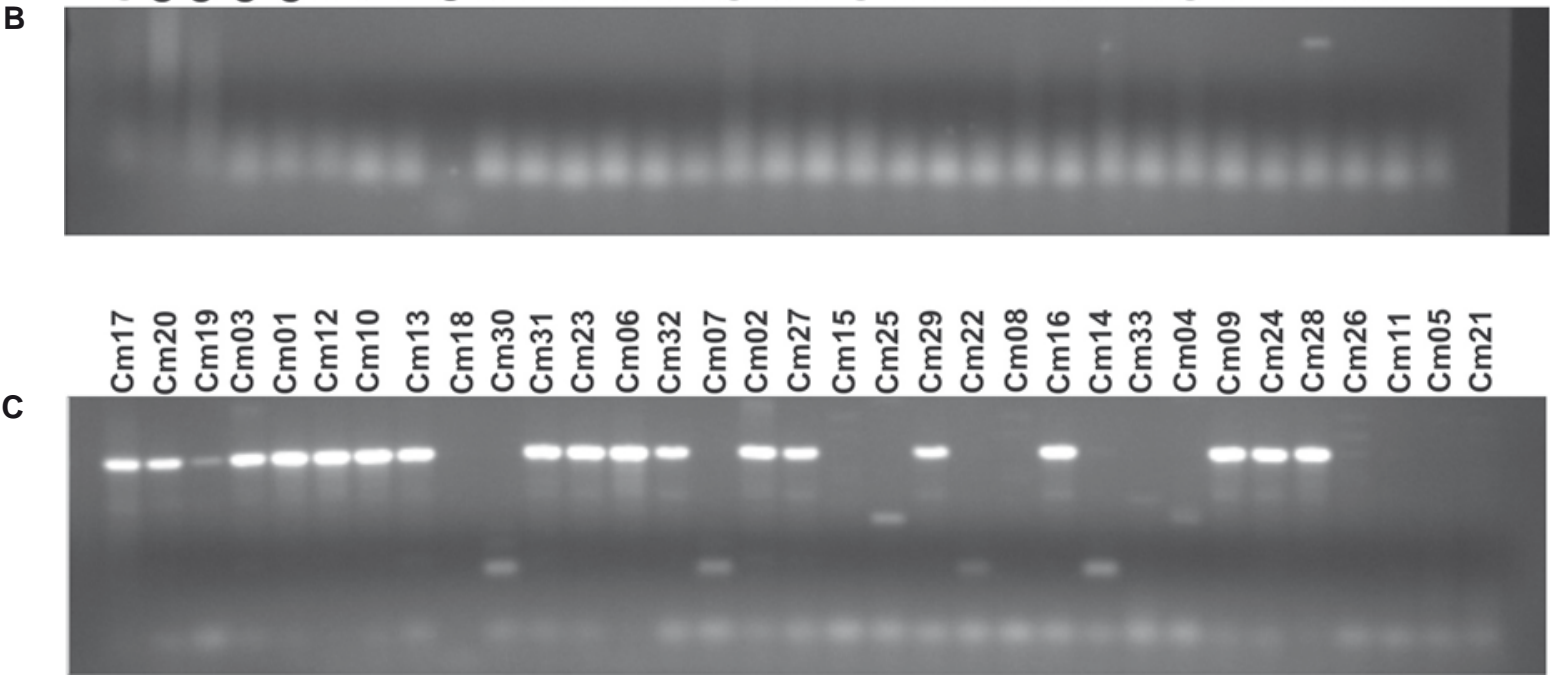

FIG. 1 - Produtos de amplificação por PCR de DNAs de 33 isolados de Colletotrichum spp. usando o primer ITS4 combinado com um dos primers do ITS1. A. CaInt2, desenhado para C. acutatum; B. CgInt, desenhado para C. gloeosporioides; C. Col1, desenhado para Colletotrichum de Passiflora.

os isolados $\mathrm{Cm} 1,2,3,6,9,10,12,13,16,17,20,23,24$, 27, 28 e 29, serão considerados como Colletotrichum sp. idênticos aos de Passiflora da Colômbia, entre os 18 isolados cujos DNAs reagiram com o primer Col1; e os isolados Cm19, 30, 7, 25, 22, 8, 14, 35, 4 e 26, cujos DNAs não reagiram com o primer Col1, serão tidos como Colletotrichum sp. de maracujá amarelo.

Além do primer CgInt, existe outro, do ITS (GACCCTCCCGGCCTCCCGCC) desenhado para identificar isolados de C. gloeosporioides do morangueiro (Xiao et al., 2004). A existência de mais de um primer específico do ITS para C. gloeosporioides confirma a sua heterogeneidade, caracterizada por exibir variações morfológicas e patogênicas (Manners et al., 1992), principalmente evidenciada em meio de cultura (Sutton, 1992), e que pode ser explicada pela ocorrência da forma sexuada, da heterocariose e da parasexualidade (Bryson et al., 1992), justificando a conotação de espécie-grupo (Manners et al., 1992). A diversidade observada entre os isolados, identificados morfologicamente como $C$. gloeosporioides e $C$. acutatum, mostrou que os primers específicos CaInt2, CgInt e Col1 não foram adequados para identificá-los a nível de espécie. De acordo com Freeman et al (1998), análise baseada em rDNA é adequada como uma ferramenta taxonômica para identificação de espécies e para detectar patógenos em plantas, mas não para revelar subpopulações dentro de uma espécie.

\section{Estudo da agressividade dos isolados de Colletotrichum sobre maracujá amarelo}

Os 33 isolados de Colletotrichum spp. inoculados nos frutos de maracujá mostraram agressividade variada, com lesões de diâmetros diferentes, suficientes para separálos em dois grupos de agressividade: alta (GA-1) e baixa (GA-2) (Tabela 1). A variação de agressividade também foi demonstrada por Assunção (1997) em isolados de $C$. gloeosporioides de cebola.

Nos dois grupos de agressividade foram detectados isolados anamórficos (reprodução assexuada) e teleomórficos (reprodução sexuada) (Tabela 1). Os anamórficos ocorreram nas três regiões amostradas, mas os teleomórficos, em sua maioria, foram encontrados na região AGR e apenas um isolado na região ZMN, que leva supor ser o ambiente AGR mais favorável à reprodução sexuada. As culturas re-isoladas foram iguais às usadas na inoculação, tomando-se como base as características morfológicas macro e microscópicas.

A demonstração da existência de isolados de 
Colletotrichum spp. com maior agressividade que outros, constitui uma informação importante para que sejam usados os de maior agressividade em programa de seleção de maracujazeiro visando a resistência à antracnose, independentemente desses isolados terem sido identificados a nível de espécie, embora essa identificação possa ser realizada posteriormente.

Correlação da agressividade dos isolados de Colletotrichum com a produção de enzimas hidrolíticas extracelulares e com o crescimento micelial

Todos isolados de Colletotrichum deste estudo apresentaram atividades para degradação dos seguintes substratos, e foram separados em grupos em função do diâmetro dos halos produzidos: amido, degradação caracterizada por halo translúcido com coloração amarelada, gerou 14 grupos; celulose, degradação identificada pelo halo opaco e estreito, resultou em sete grupos; proteína, degradação observada como halo translúcido, produziu 12 grupos; e lipídio, degradação expressa como halo na forma de precipitado, resultou em dez grupos, com exceção do isolado Cm19, um possível mutante que não degradou este substrato (Tabela 2). Porém, a metodologia usada neste ensaio não permitiu a detecção da atividade pectinolítica.

Lima Filho et al. (2003) observaram que isolados de Colletotrichum de cinco hospedeiros, incluindo o

TABELA 2 - Atividades amilolítica, celulolítica, lipolítica e proteolítica de isolados de Colletotrichum spp. de maracujá amarelo submetidos a substratos sólidos específicos

\begin{tabular}{|c|c|c|c|c|c|c|c|}
\hline \multicolumn{8}{|c|}{ Atividade } \\
\hline \multicolumn{2}{|c|}{ Amilolítica } & \multicolumn{2}{|c|}{ Celulolítica } & \multicolumn{2}{|c|}{ Lipolítica } & \multicolumn{2}{|c|}{ Proteolítica } \\
\hline Isolado & $\begin{array}{l}\text { Halo }^{1} \\
(\mathrm{~mm})\end{array}$ & Isolado & $\begin{array}{l}\text { Halo }^{1} \\
(\mathrm{~mm})\end{array}$ & Isolado & $\begin{array}{l}\text { Halo }^{1} \\
(\mathrm{~mm})\end{array}$ & Isolado & $\begin{array}{l}\text { Halo }^{1} \\
(\mathrm{~mm})\end{array}$ \\
\hline $\mathrm{Cm} 16$ & 54,9 A & $\mathrm{Cm} 22$ & $6,6 \mathrm{~A}$ & $\mathrm{Cm} 08$ & 46,7 A & $\mathrm{Cm} 11$ & $59,6 \mathrm{~A}$ \\
\hline $\mathrm{Cm} 15$ & 52,4 B & $\mathrm{Cm} 17$ & $5,3 \mathrm{~B}$ & $\mathrm{Cm} 33$ & $46,4 \mathrm{~A}$ & $\mathrm{Cm} 16$ & $58,3 \mathrm{~A}$ \\
\hline $\mathrm{Cm} 11$ & 51,9 B & $\mathrm{Cm} 24$ & $4,9 \mathrm{C}$ & $\mathrm{Cm} 11$ & $45,6 \mathrm{~A}$ & $\mathrm{Cm} 18$ & $58,2 \mathrm{~A}$ \\
\hline $\mathrm{Cm} 18$ & $51,3 \mathrm{~B}$ & $\mathrm{Cm} 23$ & $4,8 \mathrm{C}$ & $\mathrm{Cm} 14$ & $45,4 \mathrm{~A}$ & $\mathrm{Cm} 08$ & $58,0 \mathrm{~A}$ \\
\hline $\mathrm{Cm} 25$ & $50,6 \mathrm{C}$ & $\mathrm{Cm} 21$ & $4,7 \mathrm{C}$ & $\mathrm{Cm} 18$ & $45,0 \mathrm{~B}$ & $\mathrm{Cm} 05$ & $57,2 \mathrm{~B}$ \\
\hline $\mathrm{Cm} 08$ & $49,8 \mathrm{C}$ & $\mathrm{Cm} 03$ & $4,6 \mathrm{C}$ & $\mathrm{Cm} 16$ & 44,9 B & $\mathrm{Cm} 21$ & $56,5 \mathrm{~B}$ \\
\hline $\mathrm{Cm} 05$ & $48,6 \mathrm{D}$ & $\mathrm{Cm} 30$ & $4,6 \mathrm{C}$ & $\mathrm{Cm} 05$ & 44,2 B & $\mathrm{Cm} 23$ & $55,5 \mathrm{~B}$ \\
\hline $\mathrm{Cm} 26$ & $48,3 \mathrm{D}$ & $\mathrm{Cm} 11$ & $4,2 \mathrm{D}$ & $\mathrm{Cm} 15$ & 43,9 B & $\mathrm{Cm} 26$ & $53,0 \mathrm{C}$ \\
\hline $\mathrm{Cm} 25$ & $47,9 \mathrm{D}$ & $\mathrm{Cm} 07$ & $4,0 \mathrm{D}$ & $\mathrm{Cm} 21$ & $43,4 \mathrm{C}$ & $\mathrm{Cm} 25$ & $52,4 \mathrm{C}$ \\
\hline $\mathrm{Cm} 33$ & $47,4 \mathrm{D}$ & $\mathrm{Cm} 15$ & $4,0 \mathrm{D}$ & $\mathrm{Cm} 30$ & $43,4 \mathrm{C}$ & $\mathrm{Cm} 15$ & $52,2 \mathrm{C}$ \\
\hline $\mathrm{Cm} 30$ & $46,8 \mathrm{E}$ & $\mathrm{Cm} 18$ & $4,0 \mathrm{D}$ & $\mathrm{Cm} 23$ & $43,0 \mathrm{C}$ & $\mathrm{Cm} 33$ & $49,5 \mathrm{D}$ \\
\hline $\mathrm{Cm} 04$ & $46,3 \mathrm{E}$ & $\mathrm{Cm} 25$ & $4,0 \mathrm{D}$ & $\mathrm{Cm} 28$ & $42,9 \mathrm{C}$ & $\mathrm{Cm} 30$ & $48,0 \mathrm{E}$ \\
\hline $\mathrm{Cm} 21$ & $46,3 \mathrm{E}$ & $\mathrm{Cm} 04$ & $3,7 \mathrm{D}$ & $\mathrm{Cm} 07$ & $42,4 \mathrm{C}$ & $\mathrm{Cm} 04$ & $47,2 \mathrm{E}$ \\
\hline $\mathrm{Cm} 07$ & $44,7 \mathrm{~F}$ & $\mathrm{Cm} 31$ & $3,7 \mathrm{D}$ & $\mathrm{Cm} 22$ & $42,4 \mathrm{C}$ & $\mathrm{Cm} 07$ & $45,2 \mathrm{~F}$ \\
\hline $\mathrm{Cm} 14$ & $44,5 \mathrm{~F}$ & $\mathrm{Cm} 05$ & $3,5 \mathrm{E}$ & $\mathrm{Cm} 26$ & $42,4 \mathrm{C}$ & $\mathrm{Cm} 28$ & $44,0 \mathrm{~F}$ \\
\hline $\mathrm{Cm} 22$ & $44,5 \mathrm{~F}$ & $\mathrm{Cm} 06$ & $3,4 \mathrm{E}$ & $\mathrm{Cm} 25$ & $40,6 \mathrm{D}$ & $\mathrm{Cm} 14$ & $43,6 \mathrm{~F}$ \\
\hline $\mathrm{Cm} 28$ & $41,2 \mathrm{G}$ & $\mathrm{Cm} 08$ & $3,4 \mathrm{E}$ & $\mathrm{Cm} 04$ & $39,5 \mathrm{D}$ & $\mathrm{Cm} 22$ & $41,4 \mathrm{G}$ \\
\hline $\mathrm{Cm} 17$ & $38,8 \mathrm{H}$ & $\mathrm{Cm} 26$ & $3,4 \mathrm{E}$ & $\mathrm{Cm} 17$ & $39,4 \mathrm{D}$ & $\mathrm{Cm} 17$ & $38,6 \mathrm{H}$ \\
\hline $\mathrm{Cm} 20$ & $34,8 \mathrm{I}$ & $\mathrm{Cm} 16$ & $3,3 \mathrm{E}$ & $\mathrm{Cm} 02$ & $37,7 \mathrm{E}$ & $\mathrm{Cm} 03$ & $35,8 \mathrm{I}$ \\
\hline $\mathrm{Cm} 31$ & 34,6 I & $\mathrm{Cm} 14$ & $3,2 \mathrm{E}$ & $\mathrm{Cm} 06$ & $37,4 \mathrm{E}$ & $\mathrm{Cm} 31$ & 34,6 I \\
\hline $\mathrm{Cm} 29$ & 34,2 I & $\mathrm{Cm} 13$ & $2,5 \mathrm{~F}$ & $\mathrm{Cm} 01$ & $36,5 \mathrm{~F}$ & $\mathrm{Cm} 01$ & $31,1 \mathrm{~J}$ \\
\hline $\mathrm{Cm} 27$ & $34,1 \mathrm{I}$ & $\mathrm{Cm} 20$ & $2,5 \mathrm{~F}$ & $\mathrm{Cm} 32$ & $36,0 \mathrm{~F}$ & $\mathrm{Cm} 10$ & $30,9 \mathrm{~J}$ \\
\hline $\mathrm{Cm} 13$ & $33,5 \mathrm{I}$ & $\mathrm{Cm} 29$ & $2,5 \mathrm{~F}$ & $\mathrm{Cm} 03$ & $35,9 \mathrm{~F}$ & $\mathrm{Cm} 09$ & $30,4 \mathrm{~J}$ \\
\hline $\mathrm{Cm} 12$ & $32,7 \mathrm{~J}$ & $\mathrm{Cm} 27$ & $2,4 \mathrm{~F}$ & $\mathrm{Cm} 24$ & $34,8 \mathrm{G}$ & $\mathrm{Cm} 06$ & $30,0 \mathrm{~K}$ \\
\hline $\mathrm{Cm} 10$ & $31,8 \mathrm{~J}$ & $\mathrm{Cm} 12$ & $2,3 \mathrm{~F}$ & $\mathrm{Cm} 20$ & $34,4 \mathrm{G}$ & $\mathrm{Cm} 32$ & $29,9 \mathrm{~K}$ \\
\hline $\mathrm{Cm} 24$ & $31,8 \mathrm{~J}$ & $\mathrm{Cm} 01$ & $2,1 \mathrm{G}$ & $\mathrm{Cm} 31$ & $34,3 \mathrm{G}$ & $\mathrm{Cm} 20$ & $29,6 \mathrm{~K}$ \\
\hline $\mathrm{Cm} 09$ & $31,3 \mathrm{~J}$ & $\mathrm{Cm} 32$ & $2,1 \mathrm{G}$ & $\mathrm{Cm} 10$ & $33,9 \mathrm{G}$ & $\mathrm{Cm} 02$ & $29,0 \mathrm{~K}$ \\
\hline $\mathrm{Cm} 19$ & $30,5 \mathrm{~K}$ & $\mathrm{Cm} 19$ & $2,0 \mathrm{G}$ & $\mathrm{Cm} 09$ & $33,7 \mathrm{G}$ & $\mathrm{Cm} 13$ & $28,9 \mathrm{~K}$ \\
\hline $\mathrm{Cm} 03$ & $29,8 \mathrm{~K}$ & $\mathrm{Cm} 02$ & $1,9 \mathrm{G}$ & $\mathrm{Cm} 29$ & $33,5 \mathrm{G}$ & $\mathrm{Cm} 12$ & $28,0 \mathrm{~L}$ \\
\hline $\mathrm{Cm} 02$ & $29,3 \mathrm{~L}$ & $\mathrm{Cm} 09$ & $1,9 \mathrm{G}$ & $\mathrm{Cm} 13$ & $32,9 \mathrm{H}$ & $\mathrm{Cm} 27$ & $28,0 \mathrm{~L}$ \\
\hline $\mathrm{Cm} 06$ & $28,4 \mathrm{~L}$ & $\mathrm{Cm} 33$ & $1,8 \mathrm{G}$ & $\mathrm{Cm} 12$ & $32,7 \mathrm{H}$ & $\mathrm{Cm} 19$ & $27,6 \mathrm{~L}$ \\
\hline $\mathrm{Cm} 01$ & $26,3 \mathrm{M}$ & $\mathrm{Cm} 10$ & $1,7 \mathrm{G}$ & $\mathrm{Cm} 27$ & 30,9 I & $\mathrm{Cm} 24$ & $27,3 \mathrm{~L}$ \\
\hline $\mathrm{Cm} 32$ & $23,2 \mathrm{~N}$ & $\mathrm{Cm} 28$ & $1,7 \mathrm{G}$ & $\mathrm{Cm} 19$ & $0,0 \mathrm{~J}$ & $\mathrm{Cm} 29$ & $26,5 \mathrm{~L}$ \\
\hline $\mathrm{CV}(\%)$ & 2,8 & & 11,6 & & 3,0 & & 2,9 \\
\hline
\end{tabular}

${ }^{1}$ Média resultante de cinco repetições; valores acompanhados com mesma letra na vertical

não diferem entre si pelo teste de Scott Knott $(\mathrm{P}=0,05)$. 
maracujazeiro, apresentaram atividades amilolítica, celulolítica, lipolítica e proteolítica, que variaram entre os isolados. Assis (2001) observou diferença entre isolados de $C$. gloeosporioides de mangueira (Mangifera indica L.) quanto à atividade amilolítica e proteolítica, mas não para a celulolítica, e atribuiu esta falha ao curto período de incubação usado, que foi de cinco dias. Lima (2000) demonstrou que C. graminicola do milho (Zea mays L.) apresentou esta atividade 15 dias após incubação. No presente trabalho, os isolados apresentaram atividade celulolítica aos cinco dias, embora com halos pequenos, mas suficiente para separá-los em grupos.

No estudo do crescimento micelial em BDA, foram identificados oito grupos de isolados, diferenciados pelo tamanho da colônia (Tabela 3). Lima \& Chaves (1992) também encontraram resultados semelhantes com $C$. gossypii var. cephalosporioides do algodoeiro.

Os halos de degradação de amido, lipídio, proteína e celulose, e o crescimento micelial correlacionaramse negativamente com agressividade, cujos respectivos coeficientes de correlação (r) e probabilidade foram: $-0,27110 \quad(p=0,0004),-0,26697 \quad(p=0,0005),-0,29296$ $(p=0,0001),-0,21042(p=0,0067)$ e $-0,30107(p=<0,0001)$. Porém, de modo geral os valores de $r$ foram baixos e não permitiram desenvolver modelos matemáticos que explicassem o tamanho de lesão nos frutos, em função do diâmetro do halo de degradação dos substratos em cada um dos meios específicos ou pelo diâmetro crescimento da colônia em BDA. O CV de 48,6\% no ensaio da agressividade pode ter contribuído para os baixos valores

TABELA 3 - Crescimento micelial de isolados de Colletotrichum spp. de maracujá amarelo em meio de BDA, seis dias após inoculação

\begin{tabular}{lccc}
\hline \hline Isolado & $\begin{array}{c}\text { Diâmetro da } \\
\text { colônia }{ }^{\mathbf{1}} \mathbf{( m m )}\end{array}$ & Isolado & $\begin{array}{c}\text { Diâmetro da } \\
\text { colônia }^{\mathbf{1}} \mathbf{( m m )}\end{array}$ \\
\hline $\mathrm{Cm} 21$ & $83,6 \mathrm{a}$ & $\mathrm{Cm} 17$ & $62,3 \mathrm{~d}$ \\
$\mathrm{Cm} 08$ & $82,7 \mathrm{a}$ & $\mathrm{Cm} 31$ & $58.5 \mathrm{e}$ \\
$\mathrm{Cm} 33$ & $82,2 \mathrm{a}$ & $\mathrm{Cm} 01$ & $55,4 \mathrm{f}$ \\
$\mathrm{Cm} 18$ & $81,7 \mathrm{a}$ & $\mathrm{Cm} 03$ & $55,4 \mathrm{f}$ \\
$\mathrm{Cm} 05$ & $81,4 \mathrm{a}$ & $\mathrm{Cm} 12$ & $55,0 \mathrm{f}$ \\
$\mathrm{Cm} 15$ & $81,1 \mathrm{a}$ & $\mathrm{Cm} 02$ & $54,6 \mathrm{f}$ \\
$\mathrm{Cm} 16$ & $81,1 \mathrm{a}$ & $\mathrm{Cm} 06$ & $54,6 \mathrm{f}$ \\
$\mathrm{Cm} 23$ & $80,7 \mathrm{a}$ & $\mathrm{Cm} 20$ & $54,3 \mathrm{f}$ \\
$\mathrm{Cm} 11$ & $80,2 \mathrm{a}$ & $\mathrm{Cm} 27$ & $53,0 \mathrm{~g}$ \\
$\mathrm{Cm} 14$ & $79,6 \mathrm{~b}$ & $\mathrm{Cm} 19$ & $52,6 \mathrm{~g}$ \\
$\mathrm{Cm} 22$ & $79,5 \mathrm{~b}$ & $\mathrm{Cm} 24$ & $52,6 \mathrm{~g}$ \\
$\mathrm{Cm} 26$ & $78,0 \mathrm{~b}$ & $\mathrm{Cm} 09$ & $52,4 \mathrm{~g}$ \\
$\mathrm{Cm} 07$ & $76,9 \mathrm{~b}$ & $\mathrm{Cm} 10$ & $51,9 \mathrm{~g}$ \\
$\mathrm{Cm} 25$ & $76,8 \mathrm{~b}$ & $\mathrm{Cm} 13$ & $51,8 \mathrm{~g}$ \\
$\mathrm{Cm} 30$ & $70,9 \mathrm{c}$ & $\mathrm{Cm} 29$ & $51,0 \mathrm{~g}$ \\
$\mathrm{Cm} 04$ & $70,6 \mathrm{c}$ & $\mathrm{Cm} 32$ & $46,2 \mathrm{~h}$ \\
$\mathrm{Cm} 28$ & $63,5 \mathrm{~d}$ & & \\
\hline
\end{tabular}

${ }^{1}$ Média de cinco repetições; valores acompanhados com mesma letra na vertical não diferem pelo teste de $\operatorname{Scott} \operatorname{Knott}(\mathrm{P}=0,05) ; \mathrm{CV} 4,1 \%$ de r, apesar da homogeneidade das variâncias, confirmada pelo teste de Bartlet.

Couto et al. (2002) encontraram correlação positiva entre a atividade amilolítica e o tamanho das lesões causadas pelos isolados de C. musae em banana. Também foi positiva a correlação observada por Lima \& Chaves (1992) entre crescimento micelial de C. gossypii var. cephalosporioides e o índice de doença no algodoeiro, o que conflita com os resultados observados no presente trabalho. Essas divergências podem ser explicadas pela diferença entre as estratégias de patogenicidade, visto que as espécies de Colletotrichum produzem uma faixa ampla de enzimas capazes de destruir os componentes estruturais dos tecidos das plantas (Bailey et al., 1992). O fungo atua na busca por nutrientes, degradando várias substâncias como celulose, lipoproteínas, e entre outras o amido, para atender aos requerimentos exigidos às suas atividades fisiológicas. É nesta fase que as espécies podem se diferenciar no requerimento de amido, durante o desenvolvimento da patogênese. Esta explicação também se aplica ao crescimento micelial, porque o meio utilizado continha amido de batata.

De acordo com Bailey et al. (1992), as enzimas que degradam polímeros de pectina atuam no estabelecimento das infecções de espécies de Colletotrichum e a maceração dos tecidos. A ausência de atividade pectinolítica dos isolados estudados é um indicativo de que a metodologia usada neste trabalho não foi adequada. Assis (2001) não observou atividade pectinolítica nos isolados de $C$. gloeosporioides de manga após cinco dias de incubação, mas Lima (2000) conseguiu demonstrá-la em $C$. graminicola de milho aos 15 dias. Esta evidência leva a refletir que talvez um aumento no tempo de incubação gerasse resultado positivo neste estudo.

Portanto, a separação dos isolados em grupos por atividade enzimática e por crescimento micelial deixa de ter importância para efeito de caracterização da agressividade, mas evidenciou que os isolados utilizaram diferencialmente os substratos testados. Em experimentos futuros, recomenda-se aumentar o número de repetições para reduzir o valor do $\mathrm{CV}$, testar outra metodologia para avaliar a atividade pectinolítica e de outras enzimas, a exemplo de cutinase, aparentemente ligada à patogenicidade de Colletotrichum (Bailey et al., 1992).

\section{Análise molecular de isolados de Colletotrichum e caracterização da agressividade com primer de RAPD}

A regressão múltipla do tipo Stepwise evidenciou três marcadores de RAPD capazes de caracterizar isolados de GA-1 e GA-2. Os isolados com a mesma característica apresentaram fragmentos amplificados de DNA de mesmo tamanho no gel de agarose (marca), tomando-se como referência a posição da marca de um dos isolados observada a partir dos poços onde cada reação foi depositada, para a corrida eletroforética 
(Tabela 1). Vale ressaltar que a metodologia Stepwise não foi aplicada para um estudo de co-segregação marcacaráter em uma progênie, como é usual, mas sim para buscar uma interpretação geral da associação de marcas dentro dos isolados de Colletotrichum. Assim, há a possibilidade das associações serem devidas também a fatores evolucionários outros de distinção entre os isolados e não tão somente às ligações gênicas.

O primeiro marcador, primer OPA-9, amplificou o DNA de todos isolados, embora fracamente, do Cm5. Os isolados Cm17, 20, 19, 3, 1, 12, 10, 13, 31, 23, 6, 32 (GA-1), 2, 27 e 29 (GA-2) tiveram uma marca comum, que corresponde à quarta do isolado $\mathrm{Cm} 17$ (Figura 2A), e os dados depois de analisados por regressão Stepwise geraram $\mathrm{R}^{2}=0,506$ com Probabilidade $>\mathrm{F} 0,0001$ (Tabela 1). Este marcador possibilitou a caracterização de $85,7 \%$ dos isolados do GA-1, porque os DNAs de dois destes isolados, depois de amplificados, não apresentaram marcas na mesma posição do isolado Cm17, e resultou em erro de $15,7 \%$ ao caracterizar como pertencentes ao GA-1 três isolados do GA-2, os quais apresentaram marcas na mesma posição do Cm17 (Tabela 1). Estas falhas não teriam importância em programa de resistência genética, porque os diâmetros das lesões causadas por estes isolados estão próximos do menor valor de lesão causado pelo isolado com menor agressividade do GA-1 (Tabela 1).

O segundo marcador, primer OPN-9, também amplificou o DNA de todos isolados, mas fracamente do Cm28. Os isolados Cm15, 22, 26, 11, 5 e 21 tiveram como marca em comum a terceira do isolado Cm15 (Figura 2B), e os dados, depois de incorporados à regressão, aumentaram

A
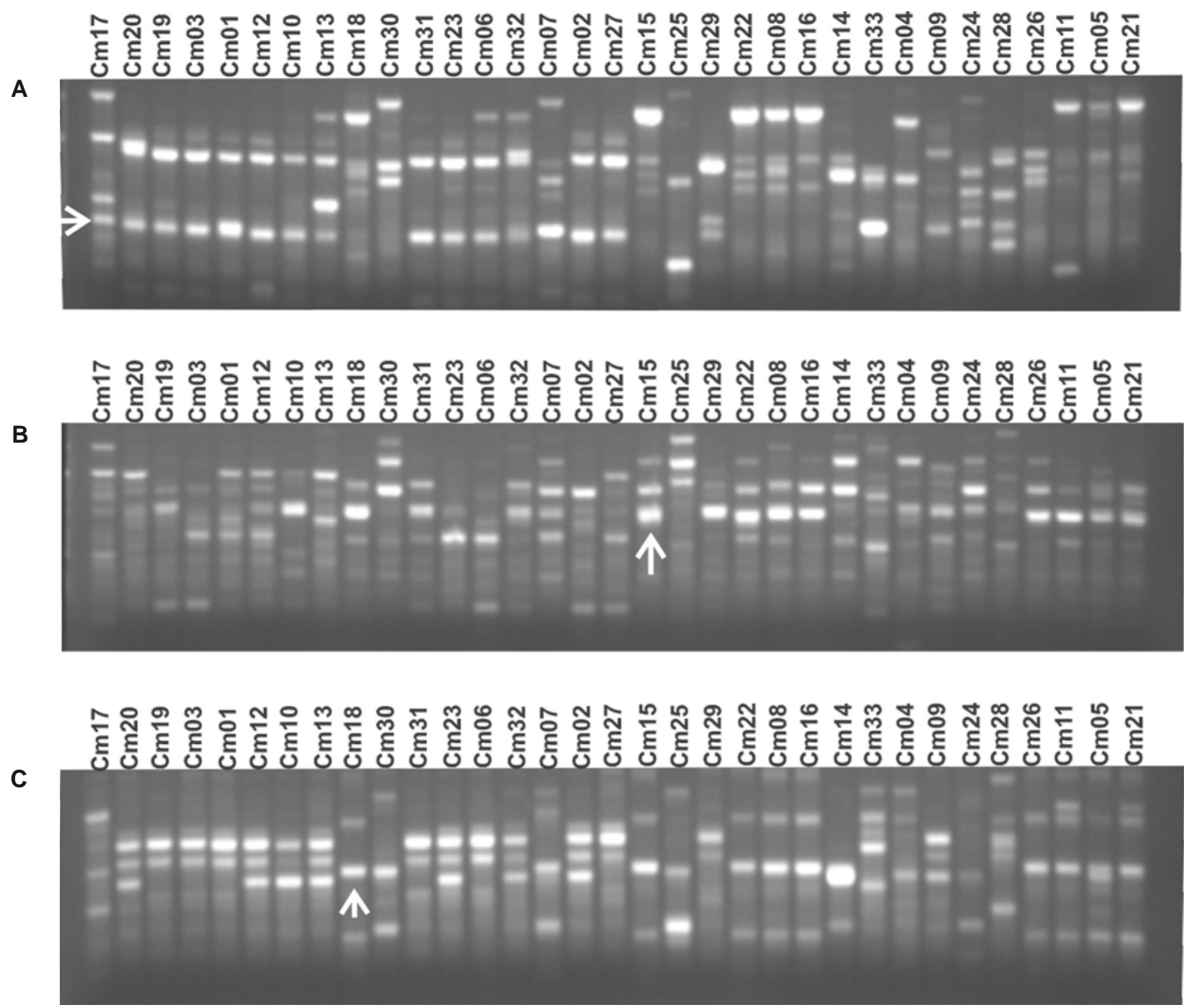

FIG. 2 - Produtos de amplificação dos DNAs genômicos em gel de agarose de 33 isolados de Colletotrichum spp. com os primers marcadores. A. OPA-9, a quarta marca do isolado Cm17 (seta) caracteriza os isolados Cm20, Cm19, Cm03, Cm01, Cm12, Cm10, Cm13, Cm31, Cm23, Cm06, Cm32, Cm02, Cm27 e Cm29; B. OPN-14, a terceira marca do isolado $\mathrm{Cm} 15$ (seta) caracteriza os isolados $\mathrm{Cm} 22, \mathrm{Cm} 26, \mathrm{Cm} 11, \mathrm{Cm} 05$ e Cm21; C. OPH-18, a segunda marca do isolado Cm18 (seta) caracteriza os isolados Cm17, Cm30, Cm07, Cm15, Cm22, Cm08, Cm16, Cm14, Cm26, Cm11, Cm05 e Cm21. 
o $\mathrm{R}^{2}$ para 0,645 com Probabilidade $>\mathrm{F} 0,0001$ (Tabela 1). Entretanto, este primer permitiu a caracterização de apenas seis isolados entre os 19 do GA-2.

O terceiro marcador, primer OPH-18, amplificou o DNA de todos os isolados, porém fracamente do Cm 24. Os isolados Cm17, 18, 30 (GA-1), 7, 15, 22, 8, 16, $14,26,11,5$ e 21 (GA-2) apresentaram marca comum, que corresponde à segunda do isolado $\mathrm{Cm} 15$ (Figura 2C), e os dados depois de incorporados à regressão elevaram o $\mathrm{R}^{2}$ para 0,733 com Probabilidade $>$ F 0,0001 (Tabela 1 ), embora sem valor prático, porque caracterizou dez isolados do GA-2 e três isolados do GA-1, sendo um deles, o $\mathrm{Cm} 17$, o mais agressivo entre os 33 isolados estudados.

Portanto, o primer OPA-9, selecionado pela regressão múltipla do tipo Stepwise, se destacou como um marcador eficiente para caracterizar os isolados de Colletotrichum spp. do GA-1 sobre maracujá amarelo.

Primers de RAPD foram utilizados para caracterizar isolados agressivos, a exemplo de Alternaria macrospora Zimm. do algodoeiro (Cassetari Neto et al., 2003), mas não foi possível caracterizar os isolados de C. gloeosporioides agressivos à manga e à cebola com os primers testados (Assis, 2001; Assunção, 1997).

A técnica RAPD tem sido considerada como de baixa reproducibilidade porque é sensível a mudanças nas condições das reações. Entretanto, resultados confiáveis são obtidos com primers do tipo SCAR (Sequence characterized amplified regions), que contêm cerca de 20 nucleotídeos, obtidos a partir de fragmentos de DNA amplificados com primers de RAPD, que se caracterizam como marcadores genéticos baseados em PCR (Paran \& Michelmore, 1993). Portanto, em estudos futuros pode-se obter um primer
SCAR a partir dos fragmentos do DNA de um dos isolados do GA-1 que foram amplificados pelo primer OPA-9. Além disso, deve-se usar um marcador de peso molecular para identificar os fragmentos de DNA a serem amplificados, em vez de identificá-los pela posição no gel, como foi realizado no presente estudo, por falta de disponibilidade do referido marcador.

O baixo polimorfismo dos fragmentos (Figura 3) não permitiu separar os isolados em grupos por origem. Assunção (1997) ao testar também primers que resultou em baixo polimorfismo com isolados de C. gloeosporioides de cebola observou resultados semelhantes, embora Swart (1999) tenha conseguido agrupar isolados de Colletotrichum de diferentes fruteiras por áreas de produção, usando primers que geraram maior número de marcas polimórficas.

As amplificações obtidas com os 18 primers testados geraram 250 fragmentos polimórficos, que permitiram estabelecer dois grupos de isolados geneticamente diferentes (Tabela 1). Os isolados Cm17, 18 e 30, apesar de pertencerem ao GA-1, foram agrupados molecularmente com aqueles do GA-2. Por outro lado, os isolados Cm2, 27, 29 e 9 do GA-2 agruparam-se com os isolados do GA-1. No estudo das dissimilaridades genéticas (Figura 3), observou-se quatro isolados do GA-2 próximos do GA-1 e três isolados do GA-1 próximos do GA-2. Porém, os isolados do GA-1 apresentaram-se mais próximos entre si do que os isolados do GA-2, evidenciando que os isolados do GA-1 evoluíram mais recentemente. A constatação de dois grupos de isolados diferentes geneticamente confirma a diversidade do patógeno, também observada em isolados de $C$. gloeosporioides da manga e da cebola (Assis, 2001 \& Assunção, 1997).

\section{Agressividade alta}

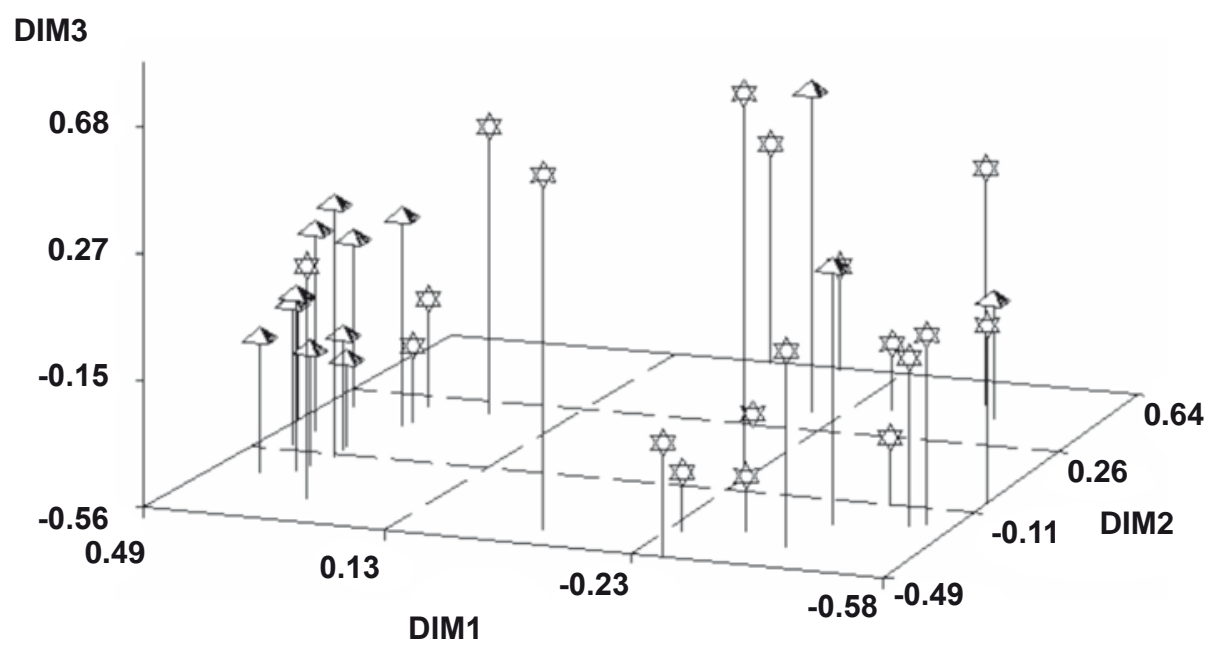

FIG. 3 - Distribuição de 33 isolados de Colletotrichum spp. com base nas três dimensões geradas a partir das dissimilaridades genéticas entre eles. 


\section{AGRADECIMENTOS}

Os autores agradecem ao Conselho Nacional de Desenvolvimento Tecnológico e Científico, CNPq pela concessão de bolsa de estudo ao primeiro autor e pelo financiamento parcial dos experimentos; à Dra. Karina Peres Gramacho e ao Dr. Jorge Teodoro de Souza pelas sugestões nos ensaios com RAPD; às biólogas Rita de Cássia Siqueira Bahia, Acassi Batista Flores e Brena Farias Santos e ao laboratorista Reinaldo Figueiredo dos Santos, pela ajuda nas reações de RAPD; ao Dr. José Luiz Pires e ao matemático Lindolfo Pereira dos Santos Filho, pelas análises dos dados com o uso do programa SAS e por colaborar na interpretação dos resultados obtidos; e ao Dr. José Luiz Bezerra, pela revisão do manuscrito.

\section{REFERÊNCIAS BIBLIOGRÁFICAS}

AFANADOR-KAFURI, L., MINZ, D. MAYMON, M. \& FREEMAN, S. Characterization of Colletotrichum isolates from tamarillo, passiflora and mango in Colombia and identification of a unique species from the genus. Phytopathology 93:579-587. 2003.

ASSIS, T.C. Variabilidade de Colletotrichum gloeosporioides, agente da antracnose da mangueira, quanto a utilização de carboidratos, patogenicidade, produção de enzimas e análise de RAPD. Dissertação de Mestrado. Recife, Universidade Federal Rural de Pernambuco. 2001.

ASSUNÇÃO, I.P. Identificação de fontes de resistência em cultivares de cebola (Allium cepa L.) e análise da variabilidade de Colletotrichum gloeosporioides (Penz.) Penz. \& Sacc. (Sensu Arx, 1957) assistida por marcadores moleculares. Dissertação de Mestrado. Recife, Universidade Federal Rural de Pernambuco. 1997.

BAILEY, J.A., O’CONNELL, R.J., PRING, R.J. \& NASH, C. Infection strategies of Colletotrichum species. In: Bailey, J.A. \& Jeger, M.J. (Eds.) Colletotrichum: biology, pathology and control. Wallingford. CABI. 1992. pp. 88-120.

BARBOSA, M.A.G. Cladosporium herbarum, agente da verrugose do maracujazeiro (Passiflora edulis, Sims.): interações com Trichoderma spp. e estudo comparativo da atividade enzimática do fitopatógeno e antagonistas. Dissertação de Mestrado. Recife, Universidade Federal Rural de Pernambuco. 1998.

BENATO, E.A. Controle de doenças pós-colheita em frutas tropicais. Summa Phytopathologica 25:90-93. 1999.

BERNSTEIN, B., ZEHR, E.I. \& DEAN, R.A. Characteristics of Colletotrichum from peach, apple, pecan, and other hosts. Plant Disease 79:478-482. 1995.

BRYSON, R.J., CATEN, C.E., HOLLOMON, D.W. \& BAILEY, J.A. Sexuality and genetics of Colletotrichum. In: Bailey, J.A. \& Jeger, M.J. (Eds.) Colletotrichum: biology, pathology and control. Wallingford. CABI. 1992. pp. 27-46.

CASSETARI NETO, D., MEHTA, Y.R., CIA, E., PIZZINATTO, M.A., TEIXEIRA, E.A. \& CUNHA, H. F. Variabilidade genética entre isolados de Alternaria macrospora do algodoeiro. Fitopatologia Brasileira 28:274. 2003. (Resumo)
COUTO, E.F., MENEZES, M. \& COELHO, R.S.B. Avaliação da patogenicidade e diferenciação de isolados de Colletotrichum musae. Summa Phytopathologica 28:260-266. 2002.

CRUZ, C.D. Programa GENES: aplicativo computacional em genética e estatística. Viçosa. UFV. 2000.

DENOYES-ROTHAN, B., GUÉRIN, G. DÉLYE, C., SMITH, B., MINZ, D., MAYMON, M. \& FREEMAN, S. Genetic diversity and pathogenic variability among isolates of Colletotrichum species from strawberry. Phytopathology 39:219-228. 2003.

DENOYES-ROTHAN, B., LAFARGUE, M. \& GUÉRIN, G. Fruit resistance to Colletotrichum acutatum in strawberries. Plant Disease 83:549-553. 1999.

FALEIRO, F.G., LUZ, E.D.M.N., CERQUEIRA, A.O., ROCHA, C.S.S., DANTAS NETO, A., FLORES, A.B., BAHIA, R.C.S. \& FALEIRO, A.S.G. Caracterização e diversidade genética de isolados de Phytophthora spp. do cacaueiro com base em marcadores RAPD. Fitopatologia Brasileira 29:303-306. 2004.

FREEMAN, S., KATAN, T. \& SHABI, E. Characterization of Colletotrichum species responsible for anthracnose diseases of various fruits. Plant Disease 82:596-605. 1998.

GUNNELL, P.S. \& GUBLER, W.D. Taxonomy and morphology of Colletotrichum species pathogenic to strawberrry. Mycologia 84:157-165. 1992

HANKIN, L. \& ANAGNOSTAKIS, S.L. The use of solid media for detection of enzime production by fungi. Mycologia 67:597607. 1975.

LIBERATO, J.R. Controle das doenças causadas por fungos, bactérias e nematóides em maracujazeiro. In: Zambolim, L., Vale, F.X.R., Monteiro, A.J.A. \& Costa, H. (Eds.) Controle de Doenças de Plantas: Fruteiras. Viçosa MG. 2002. pp. 699-825.

LIMA, E.F. \& CHAVES, G.M. Variabilidade de Colletotrichum gossypii var. cephalosporioides. Fitopatologia Brasileira 17:61-66. 1992.

LIMA, M.L.F. Caracterização patogênica, fisiológica e enzimática de isolados de Colletotrichum graminicola (Ces.) G.W. Wilson, agente causal da antracnose do milho, Zea mays L. Dissertação de Mestrado. Recife, Universidade Federal de Pernambuco. 2000.

LIMA FILHO, R.M., OLIVEIRA, S.M.A. \& MENEZES, M. Caracterização enzimática e patogenicidade cruzada de Colletotrichum spp. associados a doenças de pós-colheita. Fitopatologia Brasileira 28:620-625. 2003.

MANNERS, J.M., MASEL, A., BRAITHWAITE, K.S. \& IRWIN, J.A.G. Molecular analysis of Colletotrichum gloeosporioides pathogenic on the tropical pasture legume Stylosanthes. In: Bailey, J.A. \& Jeger, M.J. (Eds.) Colletotrichum: Biology, Pathology and Control. Wallingford. CABI. 1992. pp. 250-268. 1992.

MILLS, P.R., SREENIVASAPRASAD \& BROWN, A.E. Detection and differentiation of Colletotrichum gloeosporioides isolates using PCR. FEMS Microbiology Letters 98:137-143. 1992.

NEIROTTI, E. \& AZEVEDO, J.L. Técnica semiquantitativa de avaliação de produção de celulases em Humicola sp. Revista de Microbiologia 19:78-81. 1988.

PARAN, I. \& MICHELMORE, R.W. Development of reliable PCR-based markers linked to downy mildew resistance genes in lettuce. Theoretical and Applied Genetics 85:985-993. 1993.

PERUCH, L.A.M. Controle integrado da antracnose no maracujá 
amarelo. Dissertação de Mestrado. Florianópolis, Universidade Federal de Santa Catarina. 1998.

SAS INSTITUTE. SAS/STAT User's guide. Release 6.03. Cary, N.C. SAS Institute Inc. 1998.

SILVA, A.P. \& DURIGAN, J.F. Colheita e conservação pós-colheita do maracujá. Informe Agropecuário 21:67-71. 2000.

SREENIVASAPRASAD, S., SHARADA, K., BROWN, A.E. \& MILLS, P.R. PCR-based detection of Colletotrichum acutatum on strawberry. Plant Pathology 45:650-655. 1996.

SUTTON, B.C. The genus Glomerella and its anamorph Colletotrichum. In: Bailey, J.A. \& Jeger, M.J.(Eds.) Colletotrichum: Biology, Pathology and Control. Wallingford. CABI. 1992. pp. 1-26.

SWART, G.M. Comparative study of Colletotrichum gloeosporioides from avocado and mango. $\mathrm{PhD}$ Thesis. Pretoria, University of Pretoria. 1999.
TEIXEIRA, C.G. Cultura. In: Instituto de Alimentos. Maracujá: cultura, matéria-prima, processamento e aspectos econômicos. $2^{\text {a }}$ ed. Campinas. ITAL/IPEA. Série Frutas Tropicais, 9. 1995.

WILLIIAMS, J.G., KUBELIK, A.R., LIVAK, K.J. RAFALSKI, L.A. \& TINGEY, S.V. DNA polymorphism amplified by arbitrary primers are useful as genetic markers. Nucleic Acids Research 18:6531-6535. 1990.

WULFF, N.A., ALQUINI, Y. \& LEITE, B. Observações histopatológicas, espectrofotométricas e atividade de peroxidase em plantas de maracujá inoculadas com Colletotrichum gloeosporioides (patógeno) e Colletotrichum graminicola (não patógeno). Fitopatologia Brasileira 19:287-288. 1994. (Resumo)

XIAO, C.L., MACKENZIE, S.J. \& LEGARD, D.E. Genetic and pathogenic analyses of Colletotrichum gloeosporioides isolates from strawberry and non-cultivated hosts. Phytopathology 94:446453. 2004. 